\title{
Энергосберегающие технологии
}

УДК 662.65:662.763:621.387.14

Жовтянсъкий В.А.1, ил.-кор. НАН Украйни, докт. фіз.-мат. наук, проф., Колеснікова Е.П.2, Якимович М.В.1, канд. техн. наук,

Середенко П.А.2

1 Інститут газу НАН Украӥни, Київ

вул. Дегтярівська, 39, 03113 Київ, Україна, e-таil: zhovt@ukr.net

2 Київський політехнічний інститут імені Ігоря Сікорського, Киӥв

просп. Победы, 37, 03056 Киев, Украина, e-mail: eleonkole@ukr.net

\section{Загальні принципи переробки відходів з вилученням їхнього енергетичного потенціалу на основі плазмових технологій. 3. Порівняльний аналіз впливу кисневого й повітряного дуття та ролі калорійності донних мулів}

У розвиток циклу попередніх публікацій детально аналізуються питання визначення теплотворної здатності та ентальпії утворення донних мулів. 3 урахуванням цього аналізу уточнено показники ефективності процесу їх газифікації та проведено порівняння плазмо-паро-кисневої та плазмо-паро-повітряної технологій газифікації. При цьому на основі попередніх досліджень аналізується вплив на показники ефективності не тільки баластного азоту, але й утворення оксидів азоту, вміст яких не може бути визначений з простих термодинамічних розрахунків. Бібл. 38, рис. 6, табл. 1.

Ключові слова: небезпечні відходи, утилізація, плазмові технології, синтез-газ, донні мули станцій водоочищення, теплотворна здатність, ентальпія, кисневе та повітряне дуття, енергетична ефективність.

1. Розвиток технологій переробки небезпечних відходів із застосуванням плазмо-парової газифікації

Ця публікація підготовлена на основі матеріалів доповіді авторів на Міжнародному симпозіумі «Горіння та плазмохімія» (м. Алмати, Казахстан, 13-15 вересня 2017 р.) [1] у розвиток циклу публікацій [2, 3]. У них були розвинені загальні принципи термодинамічного аналізу ефективності переробки відходів 3 використанням плазмових технологій [2] та здій- снена їхня конкретизація щодо газифікації донних мулів станцій водоочищення [3].

У пропонованій роботі проведений детальний аналіз світової наукової літератури, який надав можливість уточнити очікувані енергетичні характеристики донних мулів як сировини для отримання синтез-газу за методом газифікації. 3 урахуванням цих результатів виконаний порівняльний аналіз ефективності процесів переробки донних мулів 3 використанням плазмових технологій у варіантах додаткового кисневого та повітряного дуття. Такі оцінки є 
важливими для прийняття остаточних рішень щодо вибору кінцевих технологічних варіантів при створенні промислової установки для переробки таких чи морфологічно подібних відходів.

Як показано в роботі [3], найбільш ефективним є поєднання у процесі переробки додаткової енергії генератора плазми, а також теплової енергії, одержуваної в результаті часткового спалювання відходів у кисневому середовищі. Перше з цих джерел гарантовано забезпечує високі термодинамічні параметри процесу газифікації у цілому некондиційного палива, яким є відходи. Однак основним джерелом введення теплової енергії в процес має бути хімічна енергія вуглецю у складі самих відходів. Особливі переваги, як випливає з попереднього розгляду, має використання пароводяної плазми, оскільки при цьому до продуктів газифікації не вноситься жоден 3 баластових газів, навпаки, вода є гарантованим джерелом водню для утворення синтез-газу $\mathrm{CO}+\mathrm{H}_{2}$. Крім того, не відбувається утворення сажі в реакторі та оксидів азоту в плазмових процесах.

Проте застосування кисню вимагає наявності в складі технологічної лінії з переробки відходів спеціального блоку розділення повітря та відповідних додаткових витрат енергії на таке обладнання та його експлуатацію. У свою чергу, пароводяні плазмотрони порівняно 3 повітряними є також більш складними та вимагають використання спеціальних вузлів приготування пари. Вони відносно недавно з'явилися у лабораторній та промисловій практиці та $є$ менш відпрацьованими, отже менш надійними.

У зв'язку з цим становить інтерес проведення спеціального кількісного зіставлення попередніх розрахунків 3 варіантом застосування повітря у технологіях газифікації.

\section{2. Енергетичні показники донних мулів}

У розвиток робіт [2, 3] у цій публікації спеціальна увага приділена визначенню енергетичних показників власне донних мулів, брутто-формула яких має вигляд $\mathrm{CH}_{2,5} \mathrm{O}_{0,5}$. Справа у тому, що в цитованих роботах величина їхньої ентальпії утворення $\Delta \mathrm{H}^{0} \mathrm{CH} 2,5 \mathrm{O} 0,5$ визначалася як різниця двох інших величин, кожна 3 яких перевищує іï майже на три порядки. Дійсно, ця величина визначається у кінцевому рахунку як різниця між сумою ентальпій продуктів газифікації $\Delta \mathrm{H}_{\mathrm{P}}$ та теплотою згоряння донного мулу $\mathrm{Q}_{\text {ндм }}[3]$ :

$$
\Delta \mathrm{H}^{0}{ }_{\mathrm{CH} 2,5 \mathrm{O} 0,5}=\Delta \mathrm{H}_{\mathrm{P}}-\mathrm{Q}_{\mathrm{H} д \mathrm{M}} .
$$

Остання оцінюється за формулою Менделєєва:

$$
\begin{gathered}
\mathrm{Q}_{\mathrm{HдM}}=-100\left[81 \mathrm{c}_{\mathrm{C}}+246 \mathrm{c}_{\mathrm{H}}-26\left(\mathrm{c}_{\mathrm{O}}{ }^{-}\right.\right. \\
\left.\left.-\mathrm{c}_{\mathrm{S}}\right)-6 \mathrm{c}_{\mathrm{W}}\right] \cdot 4,19 \text { кДж/кг, }
\end{gathered}
$$

де $\mathrm{c}_{\mathrm{C}}, \mathrm{c}_{\mathrm{H}}, \mathrm{c}_{\mathrm{O}}, \mathrm{c}_{\mathrm{S}}, \mathrm{c}_{\mathrm{W}}-$ масові частки атомів вуглецю, водню, кисню, сірки та води відповідно. Вона склала $\mathrm{Q}_{\mathrm{HдM}}=-25,68$ МДж/кг, $\Delta \mathrm{H}_{\mathrm{P}}=$ -25,74 МДж/кг.

Як результат, точність визначення величини $\Delta \mathrm{H}^{0} \mathrm{CH} 2,5 \mathrm{O}, 5 \in$ дуже невеликою. Надійною, по суті, є тільки перша значуща цифра (хоча на рівні формальних математичних операцій вона склала 76,8 кДж/кг). Більш того, значення теплоти спалювання $Q_{\text {ндм }}$, яка визначається зі згаданої напівемпіричної формули Менделєєва (2), також не може відрізнятися особливою точністю. Це зумовлюється вже іï зовнішнім виглядом, де точність подання коефіцієнтів відповідає лише двом значущим цифрам. Найкращою альтернативою було б експериментальне визначення $\mathrm{Q}_{\text {ндм у калоримет- }}$ ричній бомбі. Проте якщо ми хочемо передбачати загальні закономірності досліджуваного процесу «на кінчику пера», то необхідними є виконувані оцінки саме на основі загальних теоретичних уявлень, задовольняючись знанням цього параметра хоча б на рівні порядку величини.

У зв'язку з цим нами проведений поглиблений пошук літературних даних щодо теоретичних оцінок теплотворної здатності донних мулів [4 (с. 34-39), 5 (с. 121, 172), 6-18]. При цьому в потужному масиві англомовних публікацій 3 цього питання відсутній аналіз стосовно формули Менделєєва; про неї йдеться лише у роботах $[4,12,17]$, тобто у російськомовних. Особливої уваги заслуговує аналітична робота [6].

В останні десятиліття було встановлено [5, $6,10]$, що використання для визначення вищої теплотворної здатності традиційних емпіричних формул, які розроблялися переважно для вугілля, таких, як Дюлонга та ін. (див., наприклад, [4]), призводить до її недооцінки, якщо йдеться про біомасу, та, навпаки, до переоцінки для донних мулів. У першій з цитованих публікацій на основі методу регресійного аналізу значного масиву даних для зразків донних мулів пропонується така емпірична залежність для визначення вищої теплотворної здатності донних мулів (див. також [6]):

$$
\begin{gathered}
\mathrm{Q}_{\text {вдм }}=0,2322 \mathrm{C}+0,7655 \mathrm{H}-0,072 \mathrm{O}- \\
-0,0419 \mathrm{~N}+0,0698 \mathrm{~S}+0,0262 \mathrm{Cl}+0,1814 \mathrm{P},
\end{gathered}
$$


де позначені масові компоненти в процентах на суху беззольну масу.

Згідно з цією формулою, для нашого складу донного мулу $\mathrm{CH}_{2,5} \mathrm{O}_{0,5}$ :

$$
\begin{aligned}
& \mathrm{Q}_{\text {вдм }}=0,2322 \mathrm{C}+0,7655 \mathrm{H}-0,072 \mathrm{O}= \\
& =(0,2322 \cdot 12 / 22,5+0,7655 \cdot 2,5 / 22,5- \\
& -0,072 \cdot 8 / 22,5) \cdot 100=(0,124+0,085- \\
& \quad-0,026) \cdot 100=18,3 \text { МДж } / \text { кг. }
\end{aligned}
$$

У роботі [8] пропонується дещо інша формула (в публікації [10] на основі аналогічного методу аналізується прийнятність її застосування) для оцінок теплотворної здатності донних мулів:

$$
\begin{aligned}
& \mathrm{Q}_{\text {вдМ }}=430,2 \mathrm{C}-186,7 \mathrm{H}-127,4 \mathrm{~N}+ \\
& +178,6 \mathrm{~S}+184,2 \mathrm{O}-2379,9 \text { (кДж/кг). }
\end{aligned}
$$

Для брутто-формули $\mathrm{CH}_{2,5} \mathrm{O}_{0,5}$ результат їі застосування:

$$
\begin{gathered}
\mathrm{Q}_{\text {вдМ }}=(430,2 \cdot 12 / 22,5-186,7 \cdot 2,5 / 22,5+ \\
+184,2 \cdot 8 / 22,5) 100-2379,9(\text { кДж } / \text { кг })= \\
=22944-2074+6549-2379,9(\text { кДж } / \text { кг })= \\
=25,04 \mathrm{MДж/кг.}
\end{gathered}
$$

Ще одна залежність на основі методу регресійного аналізу запропонована в аналітичній роботі [6], яка орієнтована на використання для широкого спектру горючих речовин та може розглядатися як найбільш загальна:

$$
\begin{gathered}
\mathrm{Q}_{\text {вдМ }}=(0,3491 \mathrm{C}+1,1783 \mathrm{H}+ \\
+0,1005 \mathrm{~S}-0,1034 \mathrm{O}-0,0151 \mathrm{~N}- \\
-0,0211 \mathrm{~A}) \cdot 100(\text { МДж } / \text { кг }),
\end{gathered}
$$

де додатково до позначень хімічних елементів 3 розрахунку на суху масу включений коефіцієнт А - вміст зольної компоненти.

На її основі отримаємо:

$$
\begin{aligned}
& \mathrm{Q}_{\text {вдм }}=(0,3491 \cdot 12 / 22,5+1,1783 \cdot 2,5 / 22,5- \\
& \quad-0,1034 \cdot 8 / 22,5) \cdot 100=(0,186+ \\
& \quad+0,131-0,037) \cdot 100=28,0 \text { МДж } / \text { кг. }
\end{aligned}
$$

Як і раніше, ентальпія утворення донного

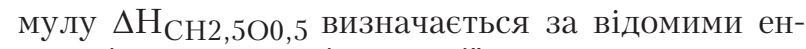
тальпіями продуктів реакції повного окислення та теплового ефекту цієї реакції. У випадку вищої теплотворної здатності слід використовувати ентальпію води у рідкому стані $\Delta \mathrm{H}_{\mathrm{H} 2 \mathrm{O}}(\mathrm{p})=$
-285,8 МДж/кмоль [19 (с. 29)]. Отже за аналогією з (1):

$$
\begin{gathered}
\Delta \mathrm{h}_{\mathrm{CH} 2,5 \mathrm{O} 0,5}=\Delta \mathrm{H}_{\mathrm{P}}-\mathrm{Q}_{\mathrm{HдД}}=\Delta \mathrm{h}^{0}{ }_{\mathrm{CO} 2}+ \\
+1,25 \Delta \mathrm{h}^{0}{ }_{\mathrm{H} 2 \mathrm{O}}(\mathrm{p})-\mathrm{Q}_{\mathrm{B} д \mathrm{M}}=-393,5+ \\
+1,25(-285,8)-\mathrm{Q}_{\text {вдМ }}(\mathrm{MДж} / \text { кмоль })= \\
=-750,75-\mathrm{Q}_{\text {вдМ }}(\text { МДж } / \text { кмоль })= \\
=-33,37-\mathrm{Q}_{\text {вдМ }}(\text { МДж } / \text { кг }) .
\end{gathered}
$$

Звідси випливають такі значення ентальпії утворення донного мулу, якщо підставляти в останню формулу значення $Q_{\text {вдм }} 3$ виразів (4), (6) та (8) відповідно:

$\Delta \mathrm{h}_{\mathrm{CH} 2,5 \mathrm{O} 0,5}=-15,07 ;-8,33$ та $-5,37$ МДж/кг. (10)

Контрольні розрахунки за формулою Менделєєва (2), згідно з якою в публікації [3] отримано значення $\mathrm{Q}_{\mathrm{H} д \mathrm{M}}=-25,7$ МДж/кг, дають такий результат, якщо використати їі для визначення ентальпії донного мулу на основі реакції повного окислення (1):

$$
\begin{aligned}
& \Delta \mathrm{h}_{\mathrm{CH} 2,5 \mathrm{O} 0,5}=\Delta \mathrm{h}^{0}{ }_{\mathrm{CO} 2}+1,25 \Delta \mathrm{h}^{0}{ }_{\mathrm{H} 2 \mathrm{O}}(\mathrm{r})+ \\
& +\mathrm{Q}_{\text {ндм }}=-393,5+1,25(-241,8)+ \\
& +\mathrm{Q}_{\text {ндм }}(\text { МДж/кмоль })=-695,75+ \\
& +\mathrm{Q}_{\text {ндм }}(\text { МДж/ кмоль })=-30,9+ \\
& +\mathrm{Q}_{\mathrm{ндМ}}(\text { МДж/кг })=-5,2 \text { МДж/кг. }
\end{aligned}
$$

Знаючи ентальпію донного мулу, визначену з урахуванням формули Менделєєва на основі співвідношення (11), переведемо це значення нижчої теплотворної здатності у вищу для іiї співставлення з іншими показниками:

$$
\begin{gathered}
\mathrm{Q}_{\mathrm{вдM}}=\Delta \mathrm{h}_{\mathrm{CH} 2,5 \mathrm{O} 0,5}-\Delta \mathrm{h}^{0} \mathrm{CO} 2- \\
-1,25 \Delta \mathrm{h}^{0}{ }_{\mathrm{H} 2 \mathrm{O}}(\mathrm{p})=-5,2 \cdot 22,5+ \\
+393,5+285,8(\text { МДж } / \text { кмоль })= \\
=562,3 \text { МДж } / \text { кмоль }=25,0 \text { МДж } / \text { кг. }
\end{gathered}
$$

Отже, в такому сенсі, що «використання для визначення вищої теплотворної здатності традиційних емпіричних формул, які розроблялися переважно для вугілля, таких, як Дюлонга та ін., веде до їі переоцінки для донних мулів» (див. вище), як висновок публікацій [4, $5,10]$, лише частково поширюється на формулу Менделєєва, якщо порівняти останній результат 3 іншими значеннями цього параметра згідно 3 (4), (6) та (8).

Нами отриманий діапазон можливих параметрів визначення ентальпії донного мулу зада- 
ного вище складу від нижнього значення $-15,07$ до -5,2 МДж/кг згідно 3 (11) та навіть до $-76,28$ кДж/кг, якщо розглядати також значення ентальпії, яке використане у роботі [3].

Оцінимо, наскільки прийнятним є такий діапазон невизначеності згаданого параметра. Для цього порівняємо показники ефективності газифікації при отриманому тут мінімальному значенні ентальпії донного мулу $\Delta \mathrm{h}_{\mathrm{CH} 2,5 \mathrm{O} 0,5}=$

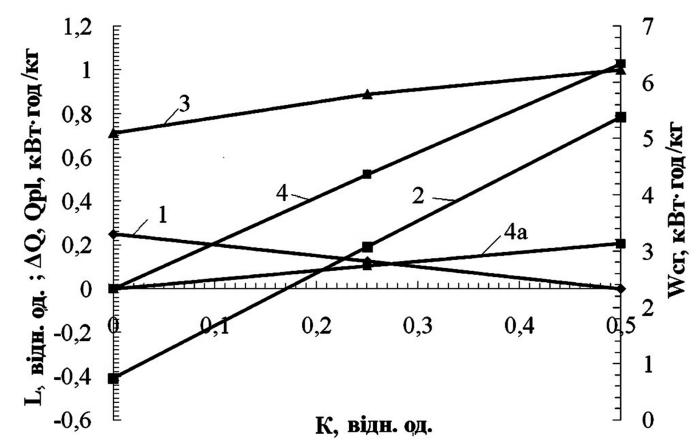

a

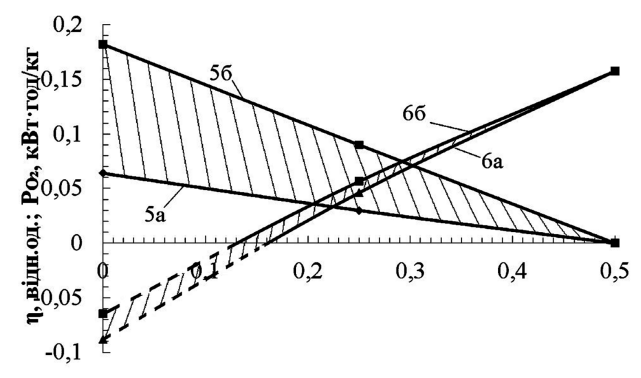

К, відн.од.

б

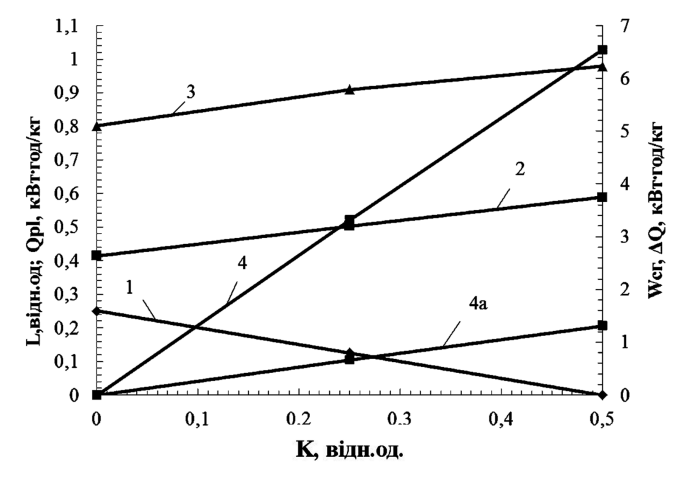

B
-15,07 МДж/кг з даними роботи [3] для стехіометричного режиму газифікації. Для зручності порівняння нижче наведено фрагмент рис.1,а,б із згаданої публікації, на якому приведені ці результати. Вони отримані на основі аналізу стехіометричної реакції газифікації [3]:

$$
\begin{gathered}
\mathrm{CH}_{2,5} \mathrm{O}_{0,5}+\mathrm{K} \mathrm{H}_{2} \mathrm{O}+\mathrm{L} \mathrm{O}_{2} \rightarrow \\
\rightarrow \mathrm{CO}+\mathrm{M} \mathrm{H}_{2}+\mathrm{Q}_{\mathrm{TP}}
\end{gathered}
$$

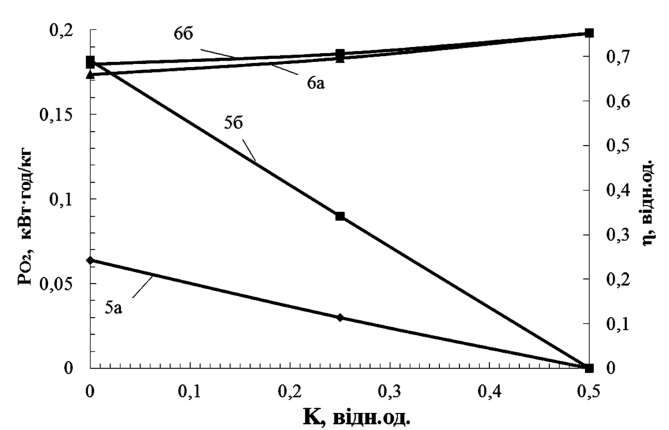

$\Gamma$

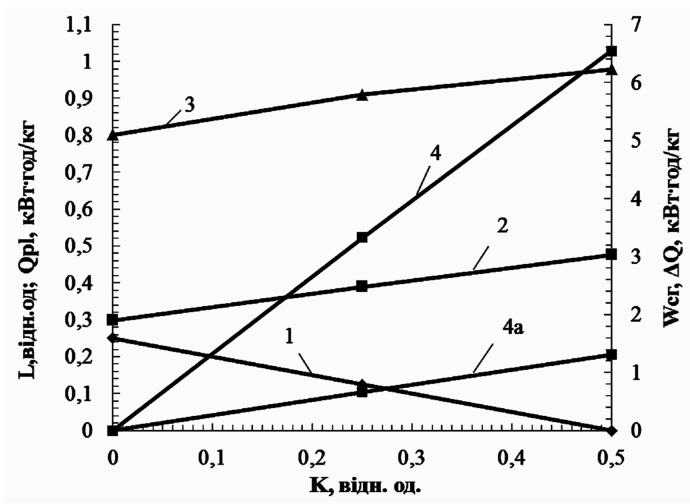

Д

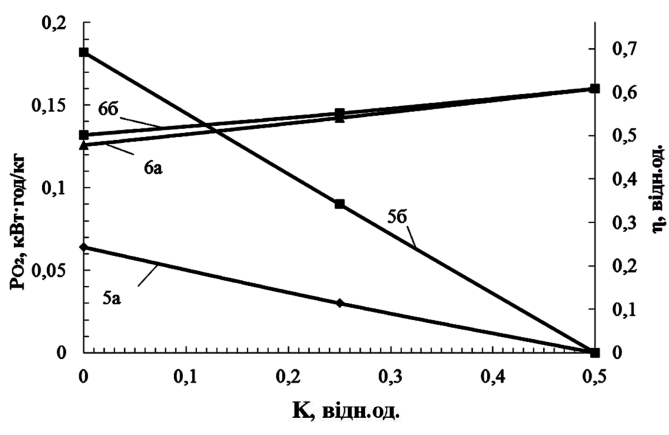

Рис.1. Основні закономірності, що характеризують стехіометричний режим паро-плазмо-кисневої газифікації донного мулу, ентальпія якого складає -76,28 кДж/кг (а, б), -11,4 МДж/кг (в, г) та -15,07 МДж/кг (д, е), у функції від уведеної в реакцію кількості водяної пари $\mathrm{K}$ - молярні та енергетичні співвідношення (а, в, д) та урахування енерговитрат на виробництво кисню та показники енергоефективвності процесу (б, г, е): 1 - вміст кисню L, що вводиться у реактор; 2 - додаткова енергія $\Delta \mathrm{Q}$, яку слід ввести в об'єм для досягнення робочої температури; 3 - енергія одержуваного синтез-газу $\mathrm{W}_{\mathrm{Cг}}$; 4, 4а - енергія, що вводиться пароводяним плазмовим струменем $\mathrm{Q}_{\mathrm{PL}}$ при його ентальпії $\mathrm{H}_{\mathrm{PL}}=3,6$ та 0,72 кВт.год/кг відповідно; 5а, $56-$ енерговитрати на виробництво кисню при питомих витратах 0,35 та 1 кВт.год/ нм³ відповідно; 6а, 66 - показники енергоефективності процесу при відповідних енерговитратах на виробництво кисню. 
де K, L, M - коефіцієнти, що визначають вміст пари, кисню та водню у продуктах реакції відповідно.

Згідно із запропонованим нами підходом до термодинамічного аналізу цього процесу [2], тут $\mathrm{Q}_{\mathrm{TP}}=\mathrm{Q}_{\mathrm{R}}+\Delta \mathrm{Q}$ - сумарна теплова енергія, складова $Q_{R}$ якої виділяється в результаті хімічних реакцій у суміші заданого складу, $\Delta \mathrm{Q}$ вводиться у реактор за допомогою додаткових джерел енергії (тут ми не обов'язково асоціюємо їх з плазмотроном) з таким розрахунком, щоб суміш, яка реагує, досягла необхідної температури $\mathrm{T}_{\mathrm{P}}$ отримання продуктів газифікації.

Для згаданих вище коефіцієнтів реакції (13) у стехіометричному режимі справедливими є залежності [3]:

$$
\begin{aligned}
& \mathrm{L}=0,25-0,5 \mathrm{~K} \\
& \mathrm{M}=1,25+\mathrm{K} .
\end{aligned}
$$

Отже на рис.1,а,б відтворені результати аналізу реакції (13), які відповідають максимальному значенню ентальпії $-76,28$ кДж/кг 3 числа наведених вище.

За повною аналогією з цими результатами, отриманими у роботі [3], на рис.1,д,е показані основні закономірності, що характеризують той самий процес стехіометричної газифікації (13) у протилежному випадку мінімального значення ентальпії донного мулу $\Delta \mathrm{h}_{\mathrm{CH} 2,5 \mathrm{O} 0,5}=-15,07$ МДж/кг. Порівнюючи рис.1, а та 1,д, слід заключити, що в останньому випадку істотно зросло значення додаткової енергії $\Delta \mathrm{Q}$, яку треба ввести в об'єм реактора для забезпечення досягнення робочої температури процесу (лінія 2 на згаданому рисунку). При значенні $\mathrm{K}=0,5$ це зростання є майже 5-кратним. Як результат, процес може бути підтриманим лише за допомогою потужного плазмотрона 3 ентальпією струменя $\mathrm{H}_{\mathrm{PL}}=3,6$ кВт.год/кг при значних витратах парової плазми, які відповідають К > 0,25.

Як і раніше, енергія отримуваного синтез-газу W (лінія 3) перевищує рівень $\Delta \mathrm{Q}$, проте тепер вона $є$ недостатньою, щоб забезпечити енергетичне самозабезпечення роботи установки 3 урахуванням ККД виробництва електроенергії на рівні $30 \%$.

Ще гіршим є те, що зникла область значень $\Delta \mathrm{Q}=\mathrm{f}(\mathrm{K})$, де $\Delta \mathrm{Q}<0$. Це означає, що тепер стали відсутніми умови безпосередньо у реакторі для плавлення мінеральної частини донних мулів (золи) за рахунок теплової енергії, яка виділяється у процесі газифікації цих мулів. Отже відносна роль поліпшення ефективності процесу при переході до нестехіометричного режиму може зменшитися.

Для звуження діапазону невизначеності був проведений пошук експериментальних даних щодо фактичної теплотворної здатності донних мулів, які дозволили б конкретизувати значення ентальпії. На основі аналізу літературних даних [20-26] можна вважати найбільш ймовірним значення $Q_{\text {вдм }}=22$ МДж/кг на суху органічну масу донних мулів, яке приведене у роботі [22] на прикладі близьких для України кліматичних умов Польщі та Німеччини. Відповідне значення ентальпії (стосовно аналізованого нами складу органічної маси) можна визначити аналогічно (9):

$$
\begin{gathered}
\Delta \mathrm{h}_{\mathrm{CH} 2,5 \mathrm{O} 0,5}=\Delta \mathrm{h}^{0}{ }_{\mathrm{CO} 2}+1,25 \Delta \mathrm{h}^{0}{ }_{\mathrm{H} 2 \mathrm{O}}(\mathrm{p})- \\
-\mathrm{Q}_{\text {вдМ }}=-33,37-\mathrm{Q}_{\text {вдМ }}(\mathrm{MДжж/кг})= \\
=-11,4 \mathrm{MДж/кг.}
\end{gathered}
$$

За аналогією $з$ цією публікацією можна визначити всі показники, що характеризують процес газифікації за реакцією (13), з використанням згаданого вище найбільш імовірного значення ентальпії. Результати таких розрахунків показані на рис.1,в,г. У цьому випадку дещо зменшився рівень додаткової енергії $\Delta \mathrm{Q}$, яку слід ввести в об'єм реактора для забезпечення досягнення робочої температури процесу (лінія 2), проте він є все ще завеликим для того, щоб забезпечити енергетичне самозабезпечення процесу газифікації.

Таким чином, для ентальпії донного мулу 3 брутто-формулою $\mathrm{CH}_{2,5} \mathrm{O}_{0,5}$ ми визначили діапазон іï можливих значень та конкретизували цей діапазон на основі літературних даних. Тим самим локалізована область можливих значень цього показника. 3 огляду на істотний вплив на характер процесу газифікації постає необхідність його конкретизації на основі безпосередніх калориметричних вимірювань. Проте, не зважаючи на те, що відносно абсолютних значень кінцевих показників ефективності процесу газифікації, нині є певна область невизначеності, отримані дані дають можливість проводити визначення загальних закономірностей газифікації при застосуванні того чи іншого фіксованого значення ентальпії.

\section{3. Порівняльний термодинамічний аналіз процесів плазмо-паро-кисневої та плазмо- паро-повітряної газифікації донних мулів}

Розглянемо узагальнену на випадок використання повітря реакцію газифікації (13) у стехіометричному режимі $[1,27]$ : 


$$
\begin{aligned}
& \mathrm{CH}_{2,5} \mathrm{O}_{0,5}+\mathrm{K} \mathrm{H}_{2} \mathrm{O}+\mathrm{L} \mathrm{O}_{2}+3,76 \mathrm{~L} \mathrm{~N}_{2} \rightarrow \\
& \quad \rightarrow \mathrm{CO}+\mathrm{M} \mathrm{H}_{2}+3,76 \mathrm{~L} \mathrm{~N}_{2}-\mathrm{Q}_{\mathrm{TP}}
\end{aligned}
$$

Тут додатково введений числовий коефіцієнт, що характеризує вміст азоту в повітрі.

Як і раніше, термодинамічний аналіз процесу конверсії донного мулу за цією реакцією, виконаний в середовищі «ТЕРPA», дав можливість визначити склад основних продуктів його плазмово-парової газифікації залежно від температури у процесі перебігу реакції; при 1250 K він практично повністю визначається іï правою частиною.

За аналогією з аналізом рівняння (13), виконаного в публікації [3], визначимо енергію $\Delta \mathrm{Q}$, яку необхідно ввести на 1 кг маси реагентів у рівняння (16) у діапазоні значень К, щоб досягти їхнього рівноважного стану при робочій температурі в реакторі газифікатора. Тут при розгляді продуктів реакції слід додатково вра-
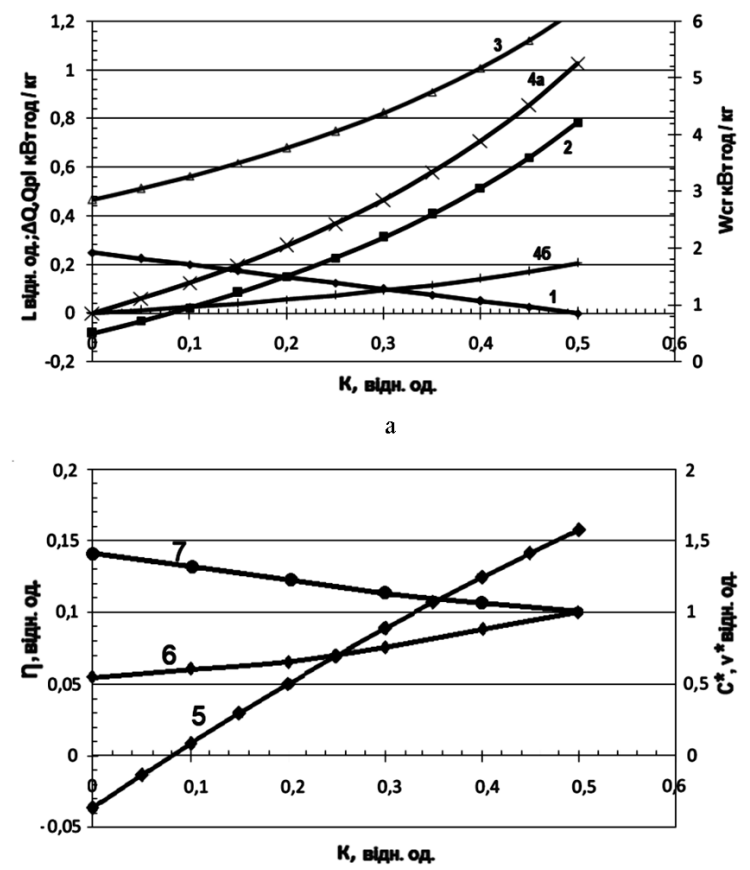

6

Рис.2. Основні характеристики стехіометричного режиму плазмо-паро-повітряної газифікації донного мулу (без урахування утворення оксидів азоту) у функції від уведеної в реакцію кількості водяної пари К - молярні та енергетичні співвідношення (а) та показники ефективності процесу (б): 1 - вміст кисню L, що вводиться в реактор у складі повітряного дуття; 2 - додаткова енергія $\Delta \mathrm{Q}$, яку слід ввести в об'єм реактора для досягнення робочої температури; 3 - енергія одержуваного синтез-газу $\mathrm{W}_{\mathrm{C}}$; 4, 4a - енергія, що вводиться пароводяним плазмовим струменем $Q_{\mathrm{PL}}$ при його ентальпії $\mathrm{H}_{\mathrm{PL}}=3,6$ та 0,72 кВт.год/кг відповідно; 5 показник енергоефективності процесу; 6 - відносний вміст донного мулу с* у суміші реагентів; 7 - відношення питомих об'ємів одержуваних продуктів газифікації. хувати ентальпію азоту, що становить 29,81 МДж/кмоль при Т = 1250 К [19 (с. 251)].

Результати розрахунків у всій області змін $\mathrm{L}$ та $\mathrm{K}$ у стехіометричному режимі наведені на рис.2. Для зручності порівняння з даними роботи [3], яким відповідає рис.1,a,б, тут прийняте значення ентальпії утворення донного мулу $\Delta \mathrm{h}^{0} \mathrm{CH} 2,5 \mathrm{O} 0,5=-76,8$ кДж/кг (як у роботі [3]). Тому отримані результати збігаються 3 даними рис.1,а,б для значень $K=0,5$. Серед характерних відмінностей слід відзначити, що в цьому випадку значно звузилася область значень К $<0,08$, де спостерігається надлишкове енерговиділення, яке може бути використаним для вітрифікації мінеральної частини донних мулів (для даних рис.1,a ця область становила $K<0,17)$.

Деяка нелінійність кривих 2-4, пов'язаних 3 енергетичними показниками на цьому рисунку, обумовлена тим, що вони віднесені до одиниці маси реагентів загалом, а не тільки до донного мулу. Таким чином, зміна вмісту води К (відповідно кисню L разом з баластним азотом) призводить до зміни питомого вмісту донного мулу $\mathrm{C}_{\text {Дм }}$ у суміші реагентів, що є джерелом хімічної енергії. Дійсно, у разі паро-кисневої газифікації, де

$$
\begin{aligned}
& \mathrm{C}_{\text {ДМ }}=\mathrm{m}_{\text {ДМ }} /\left(\mathrm{m}_{Д \mathrm{M}}+\mathrm{m}_{\mathrm{H} 2 \mathrm{O}}+\mathrm{m}_{\mathrm{O} 2}\right)= \\
& =\mathrm{M}_{\text {ДМ }} /\left(\mathrm{M}_{\text {ДM }}+\mathrm{K} \mathrm{M}_{\mathrm{H} 2 \mathrm{O}}+\mathrm{L} \mathrm{M}_{\mathrm{O} 2}\right),
\end{aligned}
$$

зміні вмісту води від $K=0$ до $K=0,5$ відповідає незначна зміна суми доданків $\left(\mathrm{K} \mathrm{M}_{\mathrm{H} 2 \mathrm{O}}+\mathrm{L} \mathrm{M}_{\mathrm{O} 2}\right)$ у знаменнику з урахуванням стехіометричного співвідношення $(14, \mathrm{a})$ від $0,25 \cdot 32=8$ до $0,5 \cdot 18=9$ (М - молярна маса). Це обумовлює лише незначну зміну величини $\mathrm{C}_{\text {дм відповідно до виразу }}$ (17), точніше у 1,033 рази.

Інша справа - паро-повітряна газифікація:

$$
\begin{gathered}
\mathrm{C}_{Д \mathrm{M}}{ }^{(1)}=\mathrm{M}_{\text {ДM }} /\left[\mathrm{M}_{Д \mathrm{M}}+\right. \\
\left.+\mathrm{K} \mathrm{M}_{\mathrm{H} 2 \mathrm{O}}+\mathrm{L}\left(\mathrm{M}_{\mathrm{O} 2}+3,76 \mathrm{M}_{\mathrm{N} 2}\right)\right] .
\end{gathered}
$$

Сума доданків $\mathrm{K} \mathrm{M}_{\mathrm{H} 2 \mathrm{O}}+\mathrm{L}\left(\mathrm{M}_{\mathrm{O} 2}+3,76 \mathrm{M}_{\mathrm{N} 2}\right)$ у тому ж діапазоні значень К змінюється від $0,25 \cdot(32+3,76 \cdot 28)=34,3$ до того ж значення 9, що і в попередньому випадку. У цілому це призведе до зміни значення $\mathrm{C}_{\text {Дм}}{ }^{(1)}$ від 0,396 до 0,714, або у 1,8 рази, у тих самих межах зміни вмісту води. Залежність відносного параметра

$$
c^{*}=\mathrm{C}_{\text {ДМ }}{ }^{(1)} / \mathrm{C}_{\text {ДМ }}
$$

від К у згаданій області представлена лінією 6 на рис.2,б. Ї̈ї відхилення у бік менших значень, а також згадане вище погіршення енергетичних 
Енергетичні характеристики плазмо-парової конверсії донного мулу в стехіометричному режимі при використанні кисневого та повітряного дуття

\begin{tabular}{|c|c|c|c|c|}
\hline Реагенти & $\begin{array}{l}\Delta \mathrm{H}_{\mathrm{R}} \\
\text { МДж/, } \\
\text { КМОль }\end{array}$ & $\begin{array}{l}\Delta Q, \\
\text { кВт год/ } \\
\text { кг* }^{*}\end{array}$ & $\begin{array}{l}\text { Wс-г, } \\
\text { кВт.год/ } \\
\text { кг* }\end{array}$ & $\underset{\text { од. }{ }^{* *}}{\eta}$ \\
\hline \multicolumn{5}{|c|}{$\mathrm{CH}_{2,5} \mathrm{O}_{0,5}+\mathrm{K} \mathrm{H}_{2} \mathrm{O}+\mathrm{LO}_{2}=\mathrm{CO}+\mathrm{M} \mathrm{H}_{2}$} \\
\hline $\mathrm{K}=0 ; \mathrm{L}=0,25$ & $-118,44$ & $0,907 / 0,67$ & $7,19 / 5,30$ & $0,167 / 0,183$ \\
\hline $\mathrm{K}=0,25 ; \mathrm{L}=0,125$ & $-178,90$ & $1,741 / 1,26$ & $7,93 / 5,75$ & $0,279 / 0,288$ \\
\hline $\mathrm{K}=0,5 ; \mathrm{L}=0$ & $-239,34$ & $2,575 / 1,83$ & $8,67 / 6,19$ & $0,371 / 0,371$ \\
\hline \multicolumn{5}{|c|}{$\mathrm{CH}_{2,5} \mathrm{O}_{0,5}+\mathrm{K} \mathrm{H}_{2} \mathrm{O}+\mathrm{L} \mathrm{O}_{2}+3,76 \mathrm{~L} \mathrm{~N}_{2}=\mathrm{CO}+\mathrm{M} \mathrm{H}_{2}+3,76 \mathrm{~L} \mathrm{~N}_{2}$} \\
\hline $\begin{array}{l}\mathrm{K}=0 ; \mathrm{L}=0,25 \\
3,76 \mathrm{~L}=0,94\end{array}$ & $-118,44$ & $1,253 / 0,496$ & $7,19 / 2,85$ & $0,218 / 0,218$ \\
\hline $\begin{array}{l}\mathrm{K}=0,25 ; \mathrm{L}=0,125 \\
3,76 \mathrm{~L}=0,47\end{array}$ & $-178,90$ & $1,914 / 0,975$ & $7,93 / 4,04$ & $0,302 / 0,302$ \\
\hline \multicolumn{5}{|c|}{$\begin{array}{l}\mathrm{CH}_{2,5} \mathrm{O}_{0,5}+\mathrm{K} \mathrm{H}_{2} \mathrm{O}+(\mathrm{L}+\Delta)(\mathrm{O} 2+3,76 \mathrm{~N} 2)= \\
\mathrm{M}_{\mathrm{H} 2}+\mathrm{c}_{\mathrm{NO}} \mathrm{NO}+\mathrm{c}_{\mathrm{NO} 2} \mathrm{NO}_{2}+\left[3,76(\mathrm{~L}+\Delta)-\left(\Delta-0,5 \mathrm{c}_{\mathrm{NO} 2}\right)\right] \mathrm{N}_{2}\end{array}$} \\
\hline $\begin{array}{l}\mathrm{K}=0,25 ; \mathrm{L}=0,125 \\
3,76 \mathrm{~L}=0,47\end{array}$ & $-178,90$ & $1,997 / 0,995$ & $7,93 / 3,95$ & $0,315 / 0,315$ \\
\hline
\end{tabular}

* У чисельнику - до кг мулу, у знаменнику - до кг суміші. ** У чисельнику - при $\mathrm{P}_{\mathrm{O} 2}=0,35$ кВт·год/кг, у знаменнику - при $\mathrm{P}_{\mathrm{O} 2}=1$ кВт.год/кг .

показників при малих значеннях К (відповідно, великих значеннях L для кисню та супутнього вмісту азоту) є взаємно обумовленими.

Як йшлося вище, з точки зору енергетичної ефективності вигідніше використовувати паро-кисневу газифікацію, але слід мати на увазі, що у варіанті повітряного дуття дана технологія дещо спрощується, що призводить до зменшення вартості обладнання та експлуатаційних витрат. Проте істотними факторами загальної вартості установки газифікації також є габарити та продуктивність очисних споруд, вартість яких може складати половину цієї вартості.

3 цієї точки зору важливим параметром є об'єм одержуваних продуктів газифікації, що обумовлює габарити та продуктивність системи їхнього очищення. Відносне збільшення об’ємів газів $\mathrm{V}^{(1)}$ та $\mathrm{V}$ на виході з реактора

$$
\mathrm{V}^{*}=\mathrm{V}^{(1)} / \mathrm{V}
$$

виходячи з реакцій газифікації (13) та (16), представлено лінією 7 на рис.2. Максимальне значення $\mathrm{v}^{*}$ становить 1,42 , та воно не $\mathrm{\epsilon}$ настільки драматичним, як можна було б очікувати, виходячи зі співвідношень питомих об'ємів азоту та кисню в повітрі. Причина цього полягає в тому, що об'єм продуктових газів визначається не тільки об'ємом вихідного окиснювача, але значною мірою питомим об'ємом водню, який безпосередньо не пов'язаний з початковим об'ємом повітря.

Проте слід мати на увазі також відмічений вище ефект впливу вмісту азоту в дуттьовому повітрі на фактичне заміщення їм донного мулу. Дійсно, відносна зміна об'єму продуктових газів згідно з (20) супроводжується зміною кількості донного мулу як сировини для газифікації в одиниці маси реагентів згідно з (19). Це означає, що хоча показник $\mathrm{v}^{*}$ відповідно до (20) і невеликий, проте 3 точки зору переробки кінцевої кількості донних мулів він має бути відкоригований на основі віднесення лише до частини сировини, яка визначається вмістом донного мулу в суміші реагентів як $\mathrm{v}^{*} / \mathrm{c}^{*}$. Максимальне значення цього відношення при $\mathrm{K}=0$ складає 2,56 , а для середнього значення $\mathrm{K}=0,25$ дещо менше $-1,8$.

Для безпосереднього кількісного зіставлення $з$ плазмо-паро-кисневою газифікацією при більш реалістичних значеннях ентальпії донного мулу $\Delta \mathrm{h}^{0} \mathrm{CH} 2,5 \mathrm{O} 0,5=-5,26$ МДж/кг (згідно 3 (12) їй відповідає вища теплотворна здатність 25,0 МДж/кг) розглянемо стехіометричний режим останньої при кількох характерних значеннях K та L. Зокрема, середньому значенню додаткового кисню $\mathrm{L}=0,125$, що вводиться у число реагентів, відповідає кількість водяної пари $\mathrm{K}=0,25$. Результати такого розгляду представлені у таблиці. Вони грунтуються на використанні термодинамічних співвідношень (1) та (2) для обчислення $\Delta \mathrm{Q}$ у реакціях (13) та (16) при обраній вище ентальпії донного мулу.

Теплотворна здатність отримуваного синтез-газу $\mathrm{W}_{\mathrm{C \Gamma}}$ визначається з урахуванням баластних компонент у продуктах газифікації:

$$
\begin{gathered}
\mathrm{W}_{\mathrm{C} \Gamma}=\left[\left(\mathrm{m}_{\mathrm{CO}} \mathrm{Q}_{\mathrm{HCO}}+\mathrm{m}_{\mathrm{H} 2} \mathrm{Q}_{\mathrm{HH} 2}\right) /\right. \\
\left./\left(\mathrm{m}_{\mathrm{CO}}+\mathrm{m}_{\mathrm{H} 2}+\mathrm{m}_{\mathrm{N} 2}\right)\right]
\end{gathered}
$$

де $\mathrm{Q}_{\mathrm{HCO}}, \mathrm{Q}_{\mathrm{HH} 2}$ - теплотворні здатності монооксиду вуглецю та водню, кВт.год/кг, $Q_{\mathrm{HCO}}=$ $=2,8, \mathrm{Q}_{\mathrm{HH} 2}=33,6$.

Як і в публікації [3], показником енергетичної ефективності процесу газифікації є

$$
\eta=\left(\mathrm{P}_{\mathrm{PL}}{ }^{\mathrm{C}}+\mathrm{P}_{\mathrm{O} 2}\right) / \mathrm{W}_{\mathrm{C} \Gamma}
$$


де ураховані витрати електричної енергії $\mathrm{P}_{\mathrm{PL}}{ }^{\mathrm{C}}$ на продукування плазмового струменя ККД плазмотрона на рівні близько 0,8 , тобто $\mathrm{P}_{\mathrm{PL}}{ }^{\mathrm{C}}=$ $=\Delta \mathrm{Q}_{\mathrm{PL}} / 0,8$, проте у цьому випадку складова витрат на виробництво кисню $\mathrm{P}_{\mathrm{O} 2}=0$.

Таким чином, зміна складу продуктів газифікації внаслідок вмісту азоту теж стає одним з факторів, які безпосередньо впливають на енергетичну ефективність установки газифікації. 3 таблиці можна зробити висновок, що у випадку повітряного дуття навіть з урахуванням відсутності додаткових витрат енергії на виробництво кисню енергетична ефективність процесу газифікації $\eta$ погіршується; крім того, зростають витрати на систему очищення продуктів газифікації внаслідок зростання їхнього фізичного об’єму.

Можна порівняти ефективність процесів у кількісному відношенні для однакової кількості води, що вводиться в процес, $К=0,25$ (це відповідае доволі реалістичній вологості органічної частини донних мулів 16,6 \%), тоді зростання енергетичних витрат на переробку одиниці маси донних мулів у випадку питомих витрат на виробництво кисню $\mathrm{P}_{\mathrm{O} 2}=$ $=0,35$ кВт.год $/$ кг складатиме $\Delta \eta=(0,302-$ $0,279) / 0,279=0,082$, або $8,2 \%$, як це випливає 3 даних таблиці. Ці дані віднесені при порівнянні до найбільш ефективної технології паро-плазмо-кисневої газифікації при мінімальних енергетичних витратах на виробництво кисню. Якщо порівнювати $\Delta \eta$ з процесом, в якому $\mathrm{P}_{\mathrm{O} 2}=1$ кВт.год / кг, то різниця у показниках енергетичної ефективності є ще меншою та складає 4,8 \% .

Проте слід ураховувати, що при переході до паро-плазмо-повітряної газифікації має місце одночасне зростання об'єму продуктів газифікації. Якщо його привести до одиниці маси донних мулів, то, згідно з даними рис.2, для $\mathrm{K}=0,25$ воно складає $\Delta(\mathrm{v} / \mathrm{c})=130 \%$. Воно $є$ доволі значним, проте не настільки, як можна було б очікувати, виходячи зі співвідношення питомих об'ємів азоту та кисню у повітрі. Причина цього полягає в тому, як уже відмічалося, що об'єм продуктових газів визначається не тільки об'ємом вихідного окиснювача, але значною мірою питомим об'ємом водню, який безпосередньо не пов'язаний з початковим об'ємом повітря.

Зростання об’єму відхідних газів вимагає адекватного урахування з точки зору продуктивності системи очищення відхідних газів та відповідного зростання капітальних витрат на її будівництво.

\section{4. Особливості урахування утворення оксидів азоту в процесах газифікації з використанням плазмо-повітряної технології донних мулів}

Більш тонким ефектом є урахування витрат енергії на утворення $\mathrm{NO}_{\mathrm{x}}$, якщо в технологічному процесі використовується не паровий, а повітряний плазмотрон. Принциповою особливістю цього урахування є некоректність застосування рівноважних значень вмісту $\mathrm{NO}_{\mathrm{x}}$ в продуктах газифікації. Тому тут використані результати наших попередніх досліджень [28], що грунтуються на строгих кінетичних розрахунках.

Суть цієї проблеми витікає з публікації Ю.П.Райзера [29], який у розвиток піонерської роботи Я.Б.Зельдовича з колегами [30] аналізував процеси в епіцентрі ядерного вибуху. Він показав, що при температурах на рівні тисяч градусів у повітрі йде інтенсивна реакція сполучення кисню та азоту, в результаті якої окислюється кілька відсотків азоту (рис.3, крива 1). При цих температурах частина утворюваного оксиду азоту на рівні 1 \% окислюється до діоксиду азоту (саме він визначає характерні оптичні властивості ядерного вибуху - його рудий колір, оскільки добре поглинає видиме світло) [31].

3 точки зору екологічної безпеки більш важливою є та обставина, що загальноприйняті гранично допустимі концентрації (які відповідають також національним санітарним нормам для населених місць [32]) для діоксиду азоту є більш жорсткими, ніж для його оксиду, та мають такі максимальні разові значення: ГДК $\left(\mathrm{NO}_{2}\right)=0,085 \mathrm{мг} / \mathrm{M}^{3} ;$ ГДК $(\mathrm{NO})=0,4 \mathrm{мг} / \mathrm{M}^{3}$.

Оксид азоту, що утворився при високих температурах, не розпадається при охолодженні повітря, оскільки швидкість реакції надзвичайно різко падає при зниженні температури в цьому полягає так званий ефект «загартування». Раніше він розглядався нами на рівні оцінок [33, 34], виходячи із зіставлення характерного часу перебігу кожної з основних хімічних реакцій утворення оксидів азоту та про-

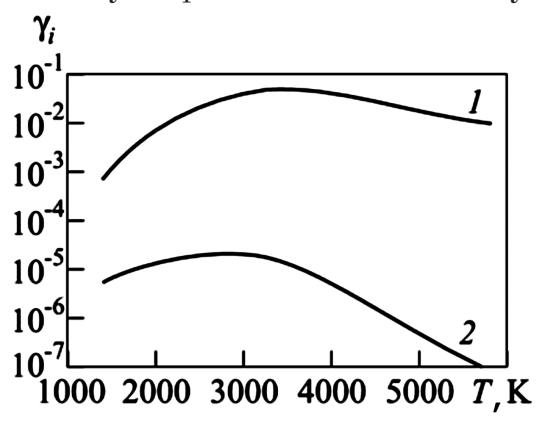

Рис.3. Рівноважні значення молярних часток $\mathrm{NO}$ (1) та $\mathrm{NO}_{2}$ (2) у сухому повітрі в функції від температури. 
цесів генерування плазми у плазмотроні, її поширення у струмені на виході плазмотрона та часу перебування в реакторі газифікатора. 3 цих оцінок випливає, що у струмені плазмотрона починає спостерігатися відхилення від рівноважного значення концентрації $\mathrm{NO}$, а концентрація $\mathrm{NO}_{2}$ зберігає своє рівноважне значення; далі, в самому реакторі, NO продовжує залишатися у нерівноважному стані, $\mathrm{NO}_{2}$ також переходить у нерівноважний, проте зберігає своє рівноважне значення при поточній температурі по відношенню до згаданого нерівноважного значення NO, з яким вони сильно пов'язані на основі реакції

$$
\mathrm{NO}+\mathrm{O}_{2}=\mathrm{NO}_{2}+\mathrm{O} \text {. }
$$

Ці оцінки підтверджуються та деталізуються кінетичними розрахунками [28]. У них прийнята модель плазмового реактора для газифікації, яка має три зони.

У першій зоні, що відповідає міжелектродному проміжку плазмотрона, газ, який використовується для генерування плазми, нагрівається від деякої початкової температури $\mathrm{T}_{0}=$ $=1000 \mathrm{~K}$ (iї рівень істотного значення не має) до температури у дузі $\mathrm{T}_{\mathrm{pl}}$ за час $\tau_{\mathrm{h}}=10^{-5} \mathrm{c}$ відповідно до часової залежності:

$$
\mathrm{T}(\mathrm{t})=\mathrm{T}_{\mathrm{pl}} *-\left(\mathrm{T}_{\mathrm{pl}} *-\mathrm{T}_{0}\right) \cdot \exp \left(-\mathrm{t} / \tau_{\mathrm{h}}\right)
$$

де параметр $\mathrm{T}_{\mathrm{pl}}{ }^{*}=8910 \mathrm{~K}$ вибирається з умови досягнення заданої температури за час $\tau_{\mathrm{h}}$.

Другій зоні відповідає швидке охолодження плазми в струмені з характерним часом $\tau_{\mathrm{j}}$ до температури $\mathrm{T}_{\mathrm{R}}$ на вході в реактор ідеального змішування. Характерний час перебування в цій зоні визначається довжиною струменя та швидкістю потоку плазми; тут прийнято значення $\tau_{\mathrm{j}}=10^{-4} \mathrm{c}$.

Третя зона визначається рухом частково охолоджених плазмоутворюючих газів та продуктових газів у реакторі та на його виході до системи охолодження, температура $\mathrm{T}_{\mathrm{D}}$ на виході якого визначається вимогами Директиви $2000 / 76 / \mathrm{CC}$, тобто 1373 К [35]. Уздовж цієї зони існує деякий градієнт температури, який прийнятий лінійним. Ї̈̈ зміну в проточному реакторі можна визначити через характерний час $\tau_{\mathrm{R}}$, причому для кінцевого часу перебування продуктів газифікації в проточному реакторі $\tau_{\mathrm{R}}=2$ с справедливе співвідношення

$$
\mathrm{T}_{\mathrm{D}}=\mathrm{T}_{\mathrm{R}}\left(1-\mathrm{t}_{\mathrm{R}} / \tau_{\mathrm{R}}\right) .
$$

$\mathrm{y}$ цьому розрахунку прийняте значення $\tau_{\mathrm{R}}=$ 10 с. Воно визначається, в кінцевому підсумку, якістю теплової ізоляції в проточному реакторі.

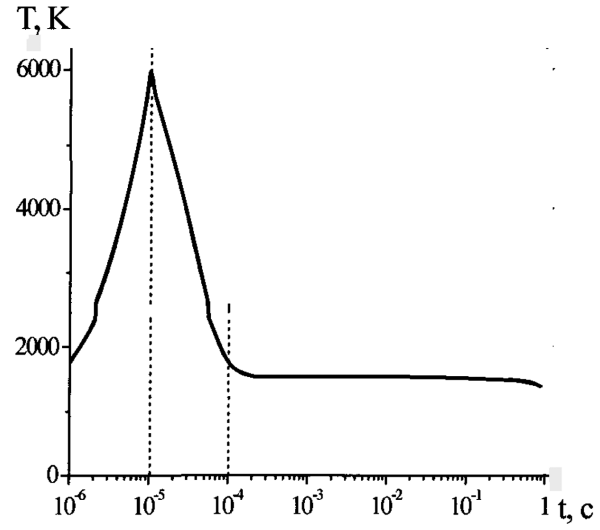

Рис.4. Типовий характер зміни поступальної температури, прийнятий для кінетичних розрахунків процесів у плазмовому реакторі.

Загалом зміна температури в цих двох 30нах охолодження може бути представлена в такий спосіб:

$$
\begin{aligned}
\mathrm{T}(\mathrm{t})= & \left(\mathrm{T}_{\mathrm{pl}}-\mathrm{T}_{\mathrm{R}}\right) \cdot \exp \left(-\left(\mathrm{t}-\tau_{\mathrm{h}}\right) / \tau_{\mathrm{j}}\right)+ \\
& +\mathrm{T}_{\mathrm{R}}\left(1-\left(\mathrm{t}-\tau_{\mathrm{h}}\right) / \tau_{\mathrm{R}}\right) .
\end{aligned}
$$

Для наочності зміна поступальної температури Т в логарифмічному масштабі часу при зазначеному наборі параметрів показана на рис.4.

Далі розглядається конкретна задача кінетики процесів хімічних перетворень у плазмовій технології при атмосферному тиску. Зокрема, розрахована концентрація компонентів суміші в реакторі. При цьому як базова використовувалася термічно нерівноважна модель, розвинена у роботі [36]. Розглядалися дві суміші: сухе повітря $\left(\mathrm{N}_{2}: \mathrm{O}_{2}=3,72: 1\right)$ та вологе повітря $\left(\mathrm{N}_{2}: \mathrm{O}_{2}\right.$ $\left.: \mathrm{H}_{2} \mathrm{O}=3,72: 1: 0,112\right)$. В останньому випадку в модель були додані реакції за участю Н-вмісних компонентів та відповідних іонів.

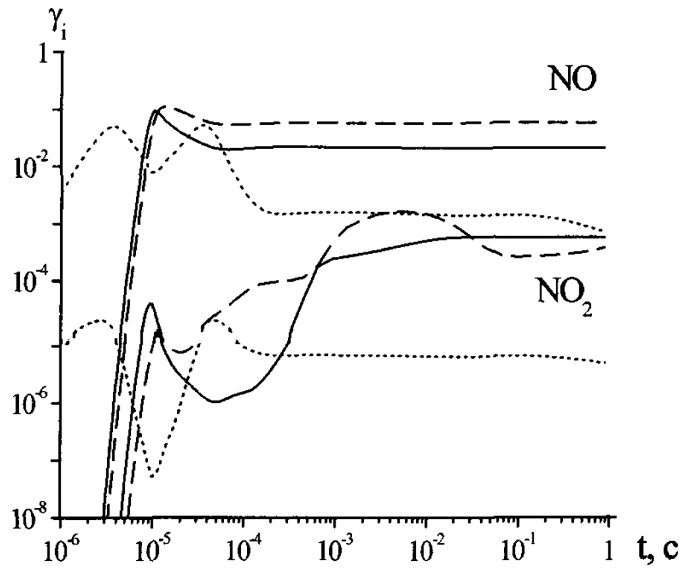

Рис.5. Зміни концентрації $\mathrm{NO}$ та $\mathrm{NO}_{2}$ в умовах функціонування газифікатора з повітряним плазмотроном. Суцільні та штрихові лінії - результати хімічно нерівноважного розрахунку, пунктирні лінії - рівноважного розрахунку. 
На рис.5 представлені результати розрахунків концентрації $\mathrm{NO}$ та $\mathrm{NO}_{2}$ при русі плазмоутворючого газу в каналі плазмотрона, в його струмені та у власне реакторі. Тут показані концентрації цих компонентів для випадків сухого (штрихові лінії) та вологого повітря (суцільні лінії), розраховані відповідно до хімічно нерівноважної моделі. Для порівняння пунктиром показані рівноважні концентрації цих компонентів у повітрі при атмосферному тиску в умовах спаду температури, заданого часовою залежністю (26).

Видно, що концентрації $\mathrm{NO}$ та $\mathrm{NO}_{2}$ не $є$ рівноважними ні в зоні нагрівання, ні після неї в зоні охолодження. Рівноважні концентрації $\mathrm{NO}_{\mathrm{x}}$ при температурі $6000 \mathrm{~K} \in$ досить низькими (ця тенденція чітко відстежується на рис.5), але при урахуванні хімічної нерівноважності їхні концентрації на виході 3 дугового розряду мають досить великі значення. Також видно, що концентрація $\mathrm{NO}_{2}$ продовжує еволюціонувати і після зони швидкого охолодження, але iï величина приблизно у 10 разів менша, ніж концентрація NO, навіть при досить великих проміжках часу перебування газу в реакторі.

Було проаналізовано вплив температури розряду на концентрацію $\mathrm{NO}_{\mathrm{x}}$ для вологого повітря та характерних значень часу $\tau_{\mathrm{h}}=10^{-4} \mathrm{c}$, $\tau_{\mathrm{j}}=10^{-4} \mathrm{c.} \mathrm{У}$ розрахунках змінювалася пікова температура розряду. Для наочності на рис.6 показані значення мольних часток $\mathrm{NO}_{\mathrm{x}} \mathrm{y}$ момент часу $\mathrm{t}=1$ с для різних температур розряду. Для $\mathrm{NO}$ та $\mathrm{NO}_{2}$ існує максимум кінцевої концентрації в області $\mathrm{T}_{\mathrm{pl}}=4500 \mathrm{~K}$. Це пов'язано 3 тим, що при менших температурах розряду оксиди азоту не встигають бути напрацьованими у достатній кількості в процесі нагрівання, а при високих температурах вони починають активно руйнуватися (у момент досягнення максимальних температур при $\mathrm{t} \sim 10^{-4}$ с у профілів $\mathrm{NO}_{\mathrm{x}}$ відзначається спад).

Наявність оксидів азоту в плазмових повітряних технологіях відзначається в експериментальних умовах згідно з публікацією [37 (с. 51)]. Аналіз утворення оксидів азоту в плазмових процесах, зокрема, газифікації вимагає розгляду кінетичних співвідношень. Але абсолютні значення їхнього вмісту навіть у випадку застосування повітряної плазми як газифікуючого агента становлять одиниці відсотків, тому при розгляді у рівноважному наближенні не спричинять істотних змін компонентного складу одержуваних продуктів газифікації. Слід особливо підкреслити у зв'язку з цим переваги застосування як газифікуючого агента пароводяної плазми, де подібна проблема не виникає

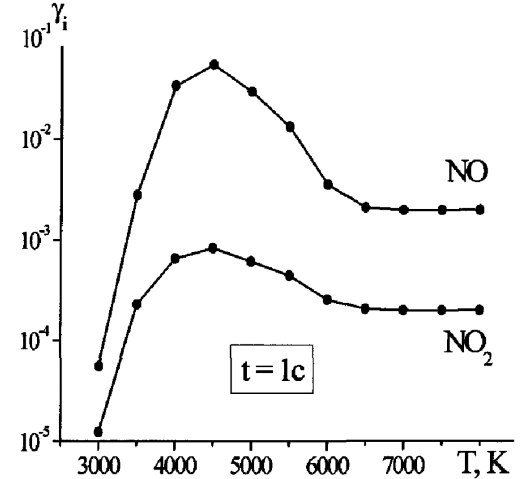

Рис.6. Молярні частки $\mathrm{NO}$ та $\mathrm{NO}_{2}$ на виході з плазмового реактора у залежності від температури в каналі плазмотрона.

взагалі. Більш того, для зниження ризику утворення паливних оксидів азоту в слабо контрольованих локальних областях взаємодії плазмового пароводяного струменя 3 газифікованою сировиною в наших розробках передбачене зниження температури струменя додатковим підмішуванням порцій холодного плазмоутворюючого газу безпосередньо на виході плазмотрона [38].

Утворення згаданих оксидів азоту вимагає певних витрат енергії. Тому доцільно кількісно оцінити вплив цього фактора на енергетику процесу газифікації. Розглянемо для цього ще більш узагальнену, ніж (16), реакцію плазмоповітряної газифікації донного мулу в стехіометричному режимі:

$$
\begin{aligned}
& \mathrm{CH}_{2,5} \mathrm{O}_{0,5}+\mathrm{K} \mathrm{H}_{2} \mathrm{O}+(\mathrm{L}+\Delta) \mathrm{O}_{2}+ \\
& +3,76(\mathrm{~L}+\Delta) \mathrm{N}_{2} \rightarrow \mathrm{CO}+\mathrm{M} \mathrm{H}_{2}+ \\
& +\mathrm{c}_{\mathrm{NO}} \mathrm{NO}+\mathrm{c}_{\mathrm{NO} 2} \mathrm{NO}_{2}+[3,76(\mathrm{~L}+ \\
& \left.+\Delta)-\left(\Delta-0,5 \mathrm{c}_{\mathrm{NO} 2}\right)\right] \mathrm{N}_{2}-\mathrm{Q}_{\mathrm{TP}} .
\end{aligned}
$$

Тут, крім числового коефіцієнта, що характеризує вміст азоту в повітрі, введені також аналогічні коефіцієнти для вмісту оксиду та діоксиду азоту в продуктах газифікації $\mathrm{c}_{\mathrm{NO}}=$ $=6,35 \cdot 10^{-2}$ та $\mathrm{c}_{\mathrm{NO} 2}=3,55 \cdot 10^{-5}$ та їх сумарний показник $\Delta=0,5 \mathrm{c}_{\mathrm{NO}}+\mathrm{c}_{\mathrm{NO} 2}$. Для оцінки цих величин використані результати вищенаведених кінетичних розрахунків (див. рис.4-6). Термодинамічно рівноважні їхні значення склали б на 1,5-2 порядки менші величини (див. рис.3).

За аналогією з аналізом рівняння (13) визначимо енергію $\Delta \mathrm{Q}(\mathrm{T})$, яку необхідно ввести на 1 кг маси реагентів у рівняння (27), щоб досягти їхнього рівноважного стану при робочій температурі в реакторі газифікатора. Тут при розгляді продуктів реакції слід додатково врахувати ентальпію при $\mathrm{T}=1250 \mathrm{~K}$ не тільки азоту (29,81 МДж/кмоль), як у рівнянні (16), але й обох оксидів, які складають, МДж/кмоль: для 
$\mathrm{NO}-(+90,29+30,88)$; для $\mathrm{NO}_{2}-(+33,10+$ $45,60)$ [19 (с. 25, 251, 269, 270)].

Як приклад для зіставлення з плазмо-паро-кисневою газифікацією, у таблиці наведені результати аналізу стехіометричного режиму останньої при середніх значеннях додаткового кисню $\mathrm{L}=0,125$, що вводиться у число реагентів. У стехіометричному режимі йому відповідає кількість водяної пари $\mathrm{K}=0,25$ (див. рис.1,a). 3 урахуванням усіх цих доданків результуюча енергія при $\mathrm{T}=1250 \mathrm{~K}$ складає $\Delta \mathrm{Q}=$ $=0,995$ кВт·год $/$ кг, якщо віднести ії̈ до одиниці маси суміші (див. таблицю).

За аналогією 3 рівнянням (21) визначається енергія синтез-газу для цих режимів газифікації, яка складає $\mathrm{W}_{\mathrm{C \Gamma}}=3,95$ кВт.год/кг (суміші).

Якщо зробити порівняння 3 висновками п.3 щодо ефективності процесів, то при К = 0,25 зростання енергетичних витрат на переробку одиниці маси донних мулів 3 урахуванням утворення оксидів азоту при використанні плазмо-повітряного дуття складе $\Delta \eta=(0,315-$ $0,279) / 0,279=0,129$, або $12,9 \%$, у випадку питомих витрат на виробництво кисню $\mathrm{P}_{\mathrm{O} 2}=$ 0,35 кВт.год/кг (див. таблицю). Якщо порівнювати 3 процесом, у якому $\mathrm{PO}_{2}=1 \kappa В$ т.год $/ \kappa г$, то різниця в показниках енергетичної ефективності складає $\Delta \eta=9,4 \%$. Таким чином, додаткове зростання енергетичних витрат в обох випадках складає майже $5 \%$.

Фактично, дані цього пункту відповідають такому варіанту технологічного процесу, в якому все повітряне дуття здійснюється за допомогою плазмотрона. У практичному сенсі це є малоймовірним, і зростання показника $\Delta \eta$ буде пропорційним частині повітря, яка проходить через плазмотрон.

\section{Висновки}

На основі детального аналізу світової наукової літератури прийняте найбільш вірогідне значення щодо теплотворної здатності донних мулів на рівні $\mathrm{Q}_{\mathrm{в} д м}=22$ МДж/кг на суху органічну масу донних мулів та відповідне йому значення ентальпії для мулів з брутто-формулою $\mathrm{CH}_{2,5} \mathrm{O}_{0,5}-(-11,4) \mathrm{M}$ Дж/кг.

Для обраного у роботі стехіометричного режиму газифікації, який допускає найбільш однозначне порівняння за показниками енергетичної ефективності, проведений аналіз процесів газифікації у варіантах плазмо-паро-кисневої та плазмо-паро-повітряної технологій газифікації. При цьому визначається вплив на показники ефективності не тільки баластного азоту, який визначається з термодинамічних міркувань, але й утворення оксидів азоту, вміст яких у продуктах газифікації був визначений попередньо на основі строгого кінетичного аналізу. Показано, що заміна кисневого дуття повітряним при середньому для умов стехіометрії режимів вмісту вологи у продуктах газифікації $\mathrm{K}=0,25$ (це відповідає доволі реалістичному вмісту водяної пари в реагентах 16,6 \%) зумовлює таке зростання енергетичних витрат на переробку одиниці маси донних мулів: у випадку питомих витрат на виробництво кисню $\mathrm{P}_{\mathrm{O} 2}=$ 0,35 кВт.год $/$ кг - на $\Delta \eta=8,2 \%$, при $\mathrm{P}_{\mathrm{O} 2}=$ 1 кВт.год/кг - на $\Delta \eta=4,8 \%$. Одночасно має місце зростання об'єму продуктів газифікації, яке складає $\Delta(\mathrm{v} / \mathrm{c})=130 \%$. Воно є доволі значним, проте не настільки, як можна було б очікувати, виходячи зі співвідношення питомих об'ємів азоту та кисню у повітрі. Причина цього полягає в тому, що об'єм продуктових газів визначається не тільки об'ємом вихідного окиснювача, але значною мірою питомим об’ємом водню, який безпосередньо не пов'язаний з початковим об'ємом повітря.

Якщо процес газифікації здійснюється у режимі, коли весь об'єм повітряного дуття є одночасно плазмоутворюючим газом, то зростання загальних енергетичних витрат на переробку одиниці маси донних мулів 3 додатковим урахуванням утворення оксидів азоту складе $\Delta \eta=$ $12,9 \%$, якщо $\mathrm{P}_{\mathrm{O} 2}=0,35$ кВт.год $/$ кг та $\Delta \eta=$ 9,4 д для $\mathrm{PO}_{2}=1$ кВт.год/кг. Таким чином, додаткова складова зростання енергетичних витрат за рахунок утворення $\mathrm{NO}_{\mathrm{x}}$ в обох випадках складає майже 5 \%.

Важливо, що зростання об'єму відхідних газів вимагає адекватного урахування 3 точки зору продуктивності системи їх очищення та відповідного зростання капітальних витрат на іï будівництво, хоча воно супроводжується економією коштів на будівництво блоку розділення повітря у випадку кисневого дуття.

Щодо кінцевих відносно невисоких абсолютних показників енергетичної ефективності процесів газифікації у цій частині циклу публікацій слід мати на увазі, що, відповідно до результатів роботи [3], найбільш ефективним є нестехіометричний режим цих процесів. $\mathrm{У}$ цій роботі такий режим не розглядався 3 метою уникнення iï переобтяження. Відповідний аналіз буде проведений окремо.

Виконання чієї роботи підтримано Міністерством освіти і науки Украӥни, проект «Розроблення та виготовлення вузлів установки для паро-плазмової переробки небезпечних відхо- 
дів», та НАН Украӥни в рамках Цільової комплексної програми наукових досліджень «Фундаментальні аспекти відновлювано-водневої енергетики $i$ паливно-комірчаних технологій» та Цільової програми наукових досліджень «Перспективні дослідження з фізики плазми, керованого термоядерного синтезу та плазмових технологій».

\section{Список літератури}

1. Жовтянский В.А., Колесникова Э.П., Якимович М.В., Середенко П.А. Сравнительный анализ эффективности плазменных технологий газификации опасных отходов. Материаль IX Международного симпозиума «Горение и плазмохимия» (г. Алматы, Казахстан, 13-15 сентября 2017 г.). Алматы : Казахский университет, 2017. С. 18-21.

2. Жовтянский В.А., Орлик В.Н., Петров В.С., Якимович М.В. Общие принципы переработки отходов с извлечением их энергетического потенциала на основе плазменных технологий. 1. Экологические требования, термодинамика процесса и его энергетическая эффективность. Энерготехнологии и ресурсосбережение. 2015. № 4. С. 24-46.

3. Жовтянский В.А., Петров С.В., Орлик В.М., Якимович М.В. Общие принципы переработки отходов с извлечением их энергетического потенциала на основе плазменных технологий. 2. Газификация иловых осадков станций водоочистки. Энерготехнологии и ресурсосбережение. 2016. № 3. С. 25-42.

4. Равич М.Б. Эффективность использования топлива. М. : Наука, 1977. 258 с.

5. Niessen W.R. Combustion and Incineration Processes. New York : Marcel Dekker Inc., 2002. 708 p.

6. Channiwala SA, Parikh PP. A unified correlation for estimating HHV of solid, liquid and gaseous fuels. Fuel. 2002. Vol. 81. P. 1051-1063.

7. Mason D.M. \& Gandhi K. Formulas for calculating the heating value of coal and coal char: development, tests and uses. ACS Division of Fuel Chemistry. Preprints. 1980. Vol. 25, № 3. P. 235-245.

8. Francis H.E. and Lloyd W.G. Predicting Heating Value from Elemental Composition. Journal of Coal Quality. 1983. Vol. 2, № 2. P. 21-25.

9. Cordero T., Marquez F., Rodriguez-Mirasol J., Rodriguez J.J. Predicting heating value of lignocellulosics and carbonaceous materials from proximate analysis. Fuel. 20001. Vol. 80, № 11. P. 1567-1571.

10. Thipkhunthod P., Meeyoo V., Rangsunvigit P., Kitiyanan B., Siemanond K. and Rirksomboon T. Sewage Sludge Heating Value Prediction through Proximate and Ultimate Analyses. Asian Journal on Energy and Environment. 2006. Vol. 7, № 2. P. 324-335.

11. Parikh J., Channiwala S.A., Ghosal G.K. A correlation for calculating elemental composition from proximate analysis of biomass materials. Fuel. 2007. Vol. 86. P. 1710-1719.

12. Зиатдинова Д.Ф., Кузьмин И.А., Садртдинов А.Р., Тимербаев Н.Ф. Исследование зависимости теплотворной способности твердых бытовых отходов
(ТБО) от их морфологического состава. Изв. вузов. Химия и хим. технология. 2008. Т. 51, № 10. C. $79-81$.

13. Shen J.S., Zhu S., Liu X., Zhang H., Tan J. The prediction of elemental composition of biomass based on proximate analysis. Energy Conversion and Management. 2010. Vol. 51. P. 983-987.

14. Erol M., Haykiri-Acma H., Kucukbayrak S. Calorific value estimation of biomass from their proximate analyses data. Renewable Energy. 2010. Vol. 35. P. $170-173$.

15. Yin C.Y. Prediction of higher heating values of biomass from proximate and ultimate analyses. Fuel. 2011. Vol. 90. P. 1128-1132.

16. Nhuchhen D.R., Abdul Salam P. Estimation of higher heating value of biomass from proximate analysis : A new approach. Fuel. 2012. Vol. 99. P. 55-63.

17. Федорова Н.И., Михайлова Е.С., Исмагилов З.Р. Зависимость теплоты сгорания углей от их химического состава. Химия в интересах устойчивого развития. 2015. Т. 23, вып. 2. С. 135-138.

18. Ozyuguran A., Yaman S. Prediction of Calorific Value of Biomass from Proximate Analysis. Energy Procedia. 2017. Vol. 107. P. 130-136.

19. McAllister S., Chen J.Y. and Fernandez-Pello A.C. Fundamentals of combustion processes (mechanical engineering series). Springer Science and Business Media. 2011. doi10.1007/978-1-4419-7943-8_2.

20. Sahu Y.K., Sahu P.K., Chakradhari S. and Patel K.S. (2016) Combustion Characteristics of Sewage Sludge and Algae. Natural Resources. 2016. Vol. 7. P. 205-213. - http://dx.doi.org/10.4236 $/ \mathrm{nr} .2016 .74019$

21. Zakaria M.S., Suhaimi Hassan and Faizairi M., Nor $M$. Calorific value of the sewage sludge in the thermal dryer. ARPN Journal of Engineering and Applied Sciences. 2015. Vol. 10, № 21. P. 10245-10248. - http://large.stanford.edu/ courses / $2017 / \mathrm{ph} 240 /$ huang1/docs / zakaria.pdf

22. Flaga $\mathrm{A}$. The aspects of sludge thermal utilization. https://www.kth.se/polopoly_fs/1.650658!/JP S11p9.pdf

23. Bouabid G., Wassate B., Touaj K., Nahya D., El Falaki K., Azzi M. Effluents treatment plants sludge characterization in order to be used as solid fuels. J. Mater. Environ. Sci. 2014. Vol. 5, № 5. P. 1583-1590. - https://www.jmaterenvironsci. com/Document/vol5/vol5_N5/194-JMES-963-20 14-Bouabid.pdf

24. Kim Y.J., Kang H.O., Qureshi T.I. Heating Value Characteristics of Sewage Sludge : A Comparative Study of Different Sludge Types. Journal of the Chemical Society of Pakistan. 2005. Vol. 27, № 2. P. 124-129.

25. Lechtenberg D. Dried sewage sludge as an alternative fuel. Global Cement Magazine. 2011. P. 36-37. - http://lechtenberg-partner.de/html/ 201104_GlobCem_Dried_Sewage_

Sludge_as_AF.pdf

26. Energy information and date. Pyromex waste to energy. 2007. p. 11. - http://www. sludgefacts.org/Ref87_2.pdf 
27. Жовтянський В.А., Колеснікова Е.П., Якимович М.В., Середенко П.А. Небезпечні відходи як відновлюване джерело енергії: порівняльний аналіз ефективності плазмових технологій газифікації. Матеріали XVI Міжнар. наук.-техн. конф. «Удосконалення енергоустановок методами математичного $i$ фізичного моделювання» (м. Харків, Україна, 11-15 вересня 2017 р.). Харків : ІПМаш, 2017. C. 51-53. - http://ipmach. kharkov.ua /downloads / conferences/WL2017-section-1.pdf .

28. Arsentiev I.V., Starik A.M., Zhovtyansky V.A. and Honcharuk Yu.A. Nonequilibrium processes of nitric oxides formation in plasma-assisted waste gasification: modeling study. Advanses in Nonequilibrium Processes: Plasma, Combustion, and Atmosphere / Ed. A.M.Starik and S.M.Frolov. Moscow : Torus Press, 2014. P. 27-33.

29. Зельдович Я.Б., Райзер Ю.П. Физика ударных волн и высокотемпературных гидродинамических явлений. М. : Наука, 1966. 688 с.

30. Зельдович Я.Б., Садовников П.Я., Франк-Каменецкий Д.А. Окисление азота при горении. М.; Л. : Изд-во АН СССР, 1947. 147 с.

31. Brage C., Qizhuang U., Sjostrom K. Use of amino phase adsorbent for biomass tar sampling and separation. Fuel. 1997. Vol. 76, № 2. P. 137-142.

32. ДСП-201-97. Державні санітарні правила охорони атмосферного повітря населених місць (від забруднення хімічними та біологічними речовина- ми). Затверджено наказом Міністерства охорони здоров’я України від 9 липня 1997 р. № 201.

33. Жовтянский В.А., Петров С.В., Колесник В.В., Орлик В.Н., Лелюх Ю.И., Невзгляд И.О., Гончарук Ю.А., Якимович М.В. Конверсия углеродсодержащего сырья с применением плазменных технологий. Энерготехнологии и ресурсосбережение. 2012. № 5. C. 15-32.

34. Zhovtyansky V.A., Petrov S.V., Lelyukh Yu.I., Nevzglyad I.O., Goncharuk Yu.A. Efficiency of Renewable Organic Raw Materials Conversion Using Plasma Technology. IEEE Trans. Plasma Sci. 2013. Vol. 41, № 12. pp. 3233-3239.

35. Directive $2000 / 76 /$ EC of the European Parliament and of the Council of 4 December 2000 on the incineration waste / / Official Journal of the European Communities L 332, 28/12/2000. pp. 91-111.

36. Dautov N.G., Starik A.M. On the choice of kinetics cheme in description of volume reaction of methane and air. Kinet. Catal. 1997. Vol. 38. pp. 168-172.

37. Ducharne C. Technical and economic analysis of Plasma-assisted Waste-to-Energy processes. Earth Engineering Centre : Columbia University. 2010. P. 50.

38. Пат. 98271 Укр., МКП ${ }^{9}$ Н 05 Н 1/24. Електродуговий плазмотрон. С.В.Петров, С.Г.Бондаренко, В.А. Жовтянський, В.М.Коржик, В.В.Попов. Заявка а201105424 від 28.04.2011 р. Опубл. 25.04.2012, Бюл. № 8 .

Надішла до редакції 20.12.17

Жовтянский В. .1 $^{1}$, чл.-корр. НАН Украины, докт. физ.-мат. наук, проф., Колесникова Э.П.2, Якимович М.В.1, канд. техн. наук, Середенко П.А.2 1 Институт газа НАН Украины, Киев ул. Дегтяревская, 39; 03113 Киев, Украина, e-mail: zhovt@ukr.net

2 Киевский политехнический институт имени Игоря Сикорского, Киев просп. Победы, 37, 03056, Киев,Украина, е-mail: eleonkole@ukr.net

Общие принципы переработки отходов с извлечением их энергетического потенциала на основе плазменных технологий 3. Сравнительный анализ влияния кислородного и воздушного дутья и роли калорийности донных илов

В развитие цикла предыдущих публикаций детально анализируются вопросы определения теплотворной способности и энтальпии образования донных илов. С учетом этого анализа уточнены показатели эффективности процесса их газификации и проведено сравнение плазменно-паро-кислородной и плазменно-паро-воздушной технологий газификации. При этом на основе предыдущих исследований анализируется влияние на показатели эффективности не только балластного азота, но и образования оксидов азота, концентрация которых не может быть определена из простых термодинамических расчетов. Библ. 38, рис. 6, табл. 1.

Ключевые слова: опасные отходы, утилизация, плазменные технологии, синтез-газ, донные илы станций водоочистки, теплотворная способность, энтальпия, кислородное и воздушное дутье, энергетическая эффективность. 
Zhovtyansky V.A.1, Corr. Member of the National Academy of Sciences

of Ukraine, Doctor of Physical and Mathematical Sciences, Professor,

Kolesnikova E.P. ${ }^{2}$, Yakymovych M.V.1, Candidate of Technical Sciences, Seredenko P.A.2

1 The Gas Institute of National Academy of Sciences of Ukraine, Kiev

39, Degtyarivska St., 03113 Kiev, Ukraine, e-mail: zhovt@ukr.net

2 Igor Sikorsky Kyiv Polytechnic Institute, Kiev

37, Peremohy Ave., 03056 Kiev, Ukraine, e-mail: eleonkole@ukr.net

\title{
The General Principles of Waste Processing with Recovery of their Energy Potential on the Basis of Plasma Technologies. Part III. Comparative Analysis of the Oxygen and Air Blowing Influence and the Role of Calorific Content of Sewage Sludge
}

\begin{abstract}
The issues of determination calorific value as well as the enthalpy of formation of sewage sludge are deeply analyzed further to previous publications. Taking into account this analysis, the indicators, the indicators of the efficiency of the sewage sludge gasification process have been clarified and a comparison of the plasma-steam-oxygen and plasmasteam-air gasification technologies has been made. At the same time, on the basis of previous studies, the influence on the efficiency indices of not only ballast nitrogen, but also nitrogen oxides is analyzed. Their concentrations cannot be determined on the basis of simple thermodynamic ratios. Bibl 38, Fig. 6, Tab. 1.

Key words: hazardous waste, processing, plasma technologies, synthesis gas, sewage sludge of wastewater treatment plants, calorific value, enthalpy, oxygen and air blowing, energy efficiency.
\end{abstract}

\section{References}

1. Zhovtyansky V.A., Kolesnikova E.P., Yakimovich M.V., Seredenko P.A. [Comparative analysis of the effectiveness of plasma technologies for the gasification of hazardous waste]. [Proceedings of the 9th International Symposium «Combustion and Plasma Chemistry»] (Almaty, Kazakhstan, Sept. 13-15, 2017). Almaty : Kazakh University, 2017. pp. 18-21. (Rus.)

2. Zhovtyansky V.A., Orlyk V.N., Petrov S.V., Iakymovych M.V. [The General Principles of Waste Processing with Recovery of their Energy Potential on the Basis of Plasma Technologies. Part I. Environmental Requirements, the Thermodynamics of the Process and its Energy Efficiency]. Energotehnologii $i$ resursosberezhenie [Energy Technologies and Resource Saving]. 2015. No. 4. pp. 24-42. (Rus.)

3. Zhovtyansky V.A., Orlyk V.N., Petrov S.V., Iakymovych M.V. [The General Principles of Waste Processing with Recovery of their Energy Potential on the Basis of Plasma Technologies. Part II. Gasification of the sewage sludge of wastewater treatment plants]. Energotehnologii $i$ resursosberezhenie [Energy Technologies and Resource Saving]. 2016. No. 3. pp. 25-46. (Rus.)

4. Ravich M.B. [Efficiency of fuel use]. Moscow : Nauka, 1977. pp. 258. (Rus.)
5. Niessen W.R. Combustion and Incineration Processes, 3rd Edition, Marcel Dekker Inc., New York. 2002. 708 p.

6. Channiwala S.A., Parikh P.P. A unified correlation for estimating HHV of solid, liquid and gaseous fuels. Fuel. 2002. 81. pp. 1051-1063.

7. Mason D.M. \& Gandhi K. Formulas for calculating the heating value of coal and coal char: development, tests and uses. ACS Division of Fuel Chemistry, Preprints. 1980. 25 (3). pp. 235-245.

8. Francis H.E. and Lloyd W.G. Predicting Heating Value from Elemental Composition, Journal of Coal Quality. 1983. 2 (2). pp. 21-25.

9. Cordero T., Marquez F., Rodriguez-Mirasol J., Rodriguez J.J. Predicting heating value of lignocellulosics and carbonaceous materials from proximate analysis. Fuel. 20001. 80 (11). pp. 1567-1571.

10. Thipkhunthod P., Meeyoo V., Rangsunvigit P., Kitiyanan B., Siemanond K. and Rirksomboon T. Sewage Sludge Heating Value Prediction through Proximate and Ultimate Analyses. Asian Journal on Energy and Environment. 2006. 7 (2). pp. 324-335.

11. Parikh J., Channiwala S.A., Ghosal G.K. A correlation for calculating elemental composition from proximate analysis of biomass materials. Fuel. 2007. 86. pp. 1710-1719.

12. Ziatdinova D.F., Kuzmin I.A., Sadriddinov A.R., Timerbaev N.F. [Investigation of the dependence of 
the heating value of solid domestic waste (MSW) on their morphological composition]. Izv. vuzov. Khimiya $i$ khim. tekhnologii [News of universities. Chemistry and Chemistry. Technologies]. 2008. 51 (10). pp. 79-81. (Rus.)

13. Shen J.S., Zhu S., Liu X., Zhang H., Tan J. The prediction of elemental composition of biomass based on proximate analysis. Energy Conversion and Management. 2010. 51. pp. 983-987.

14. Erol M., Haykiri-Acma H., Kucukbayrak S. Calorific value estimation of biomass from their proximate analyses data. Renewable Energy. 2010. 35. pp. 170-173.

15. Yin C.Y. Prediction of higher heating values of biomass from proximate and ultimate analyses. Fuel. 2011. 90. pp. 1128-1132.

16. Nhuchhen D.R., Abdul Salam P. Estimation of higher heating value of biomass from proximate analysis : A new approach. Fuel. 2012. 99. pp. 55-63.

17. Fedorova N.I., Mikhailova E.S., Ismagilov Z.R. [Dependence of the heat of combustion of coals on their chemical composition]. Khimiya $v$ interesakh ustoychivogo razvitiya [Chemistry in the interests of sustainable development]. 2015. 23. Iss. 2. pp. 135-138. (Rus.)

18. Ozyuguran A., Yaman S. Prediction of Calorific Value of Biomass from Proximate Analysis. Energy Procedia. 2017. 107. pp. 130-136.

19. McAllister, S., Chen, J.Y., Fernandez-Pello, A.C. Fundamentals of combustion processes (mechanical engineering series), Springer Science and Business Media. 2011. doi 10.1007/978-1-4419-7943-8_2.

20. Sahu Y.K., Sahu P.K., Chakradhari S. and Patel K.S. (2016) Combustion Characteristics of Sewage Sludge and Algae. Natural Resources. 2016. 7. pp. 205-213. - http://dx.doi.org/10.4236/nr. 2016.74019

21. Zakaria M.S., Suhaimi Hassan and Faizairi M., Nor $M$. Calorific value of the sewage sludge in the thermal dryer. ARPN Journal of Engineering and Applied Sciences. 2015. 10 (21). pp. 10245-10248. http: / / large.stanford.edu / courses / 2017/ph240 / huang1/docs / zakaria.pdf

22. Flaga A. The aspects of sludge thermal utilization. pp. 9-18. - https://www.kth.se/polopoly_fs 1.650658!/JPS11p9.pdf

23. Bouabid G., Wassate B., Touaj K., Nahya D., El Falaki K., Azzi M. Effluents treatment plants sludge characterization in order to be used as solid fuels. J. Mater. Environ. Sci. 2014. 5 (5). pp. 1583-1590. - https://www.jmaterenvironsci. com / Document / vol5/vol5_N5/194-JMES-9632014-Bouabid.pdf

24. Kim Y.J., Kang H.O., Qureshi T.I. Heating Value Characteristics of Sewage Sludge : A Comparative Study of Different Sludge Types. J. of the Chemical Society of Pakistan. 2005. 27 (2). P. 124-129.

25. Lechtenberg D. Dried sewage sludge as an alternative fuel. Global Cement Magazine. 2011. pp. 36-37. http: / / lechtenberg-partner.de/html/201104_Glob Cem_Dried_Sewage_Sludge_as_AF.pdf
26. Energy information and date. Pyromex waste to energy. 2007. p. 11. - http://www.sludge- facts. org/Ref87_2.pdf

27. Zhovtyansky V.A., Kolesnikova E.P., Yakimovich M.V., Seredenko P.A. [Hazardous Waste as a Renewable Energy Source: Comparative Analysis of the Efficiency of Plasma Gasification Technologies]. Materials of the 16th Intern. Sci.-Techn. Conf. «Improvement of power systems by methods of mathematical and physical modeling» (Kharkov, Ukraine, Sept. 11-15, 2017). Kharkiv : IPMash, 2017. pp.51-53. (Ukr.) - http://ipmach.kharkov. ua/downloads / conferences/WL2017-section-1.pdf

28. Arsentiev I.V., Starik A.M., Zhovtyansky V.A. and Honcharuk Yu.A. Nonequilibrium processes of nitric oxides formation in plasma-assisted waste gasification: modeling study. Advanses in Nonequilibrium Processes: Plasma, Combustion, and Atmosphere. Ed. A.M.Starik and S.M.Frolov. Moscow : Torus Press, 2014. pp. 27-33.

29. Zel'dovich Ya.B., Raiser Yu.P. [Physics of shock waves and high-temperature hydrodynamic phenomena]. Moscow : Nauka, 1966. 688 p. (Rus.)

30. Zel'dovich Ya.B., Sadovnikov P.Ya., Frank-Kamenetsky D.A. [Oxidation of nitrogen during combustion]. Moscow; Leningrad : Izdatelstvo AN USSR, 1947. 147 p. (Rus.)

31. Brage C., Qizhuang U., Sjostrom K. Use of amino phase adsorbent for biomass tar sampling and separation. Fuel. 1997. 76 (2). pp. 137-142.

32. DSP-201-97. State sanitary rules for the protection of atmospheric air of populated areas (from pollution by chemical and biological substances). Approved by the order of the Ministry of Health of Ukraine of July 9, 1997. No. 201. (Ukr.)

33. Zhovtyansky V.A., Petrov S.V., Kolesnyk V.V., Orlyk V.M., Nevzglyad I.O., Goncharuk Yu.A., and Yakymovych M.V. [Conversion of carbonaceous raw materials using plasma technology]. Energotehnologii $i$ resursosberezhenie [Energy Technologies and Resource Saving]. 2012. No. 5. pp. 15-32. (Rus.)

34. Zhovtyansky V.A., Petrov S.V., Lelyukh Yu.I., Nevzglyad I.O., Goncharuk Yu.A. [Efficiency of Renewable Organic Raw Materials Conversion Using Plasma Technology]. IEEE Trans. Plasma Sci. 2013. 41 (12). pp. 3233-3239.

35. Directive $2000 / 76 /$ EC of the European Parliament and of the Council of 4 December 2000 on the incineration waste. Official Journal of the European Communities L 332, 28/12/2000. pp. 91-111.

36. Dautov N.G., Starik A.M. On the choice of kinetics cheme in description of volume reaction of methane and air. Kinet. Catal. 1997. 38. pp. 168-172.

37. Ducharne C. Technical and economic analysis of Plasma-assisted Waste-to-Energy processes, Earth Engineering Centre: Columbia University. 2010. 50 p.

38.Pat. 98271 UA, MKP H 05 H 1/24. [Arc plasma torc]. S.V.Petrov, S.G.Bondarenko, V.A.Zhovtyansky, V.M.Korzhyk, V.V.Popov. Publ. 25.04.2012. (Ukr.)

Received December 20, 2017 